\title{
界面活性剂水溶液の泡膜特性 \\ Physical Properties of Foam Film from Surfactant Aqueous Solutions
}

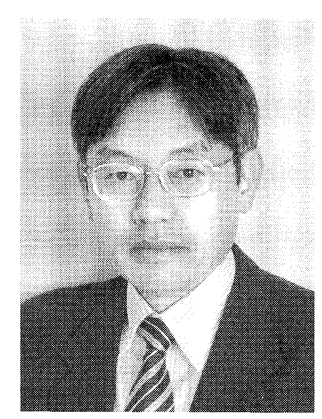

田村隆光

ライオン株式会社 化学品研究所

₹132-0035

東京都江戸川区平井 7-13-12

Takamitsu TAMURA

Chemicals Research Laboratories, Lion Corporation

13-12, Hirai 7-Chome, Edogawa-ku, Tokyo 132-0035,

JAPAN

論文要旨：泡膜は膜厚みに応じてその安定性を支配する主因子が変化する。泡膜の排液の駆動力には重力, キャピラリー圧, 表面張力があり, 排液はキャピラリー圧が泡膜の分離圧とつりあって平衡膜厚みが示され る。泡膜が厚い状態では, 流体力学的な液体物性に依存して排液が進む。その過程で熱ゆらぎが観測され, これが激しくなると局所的に液膜の両面が接触して黒膜を形成する。薄膜となると平衡膜厚みに近づくにつ れ分離圧効果が現れるため, DLVO 理論に従って電気二重層反発力とファンデルワールスカの合算で膜厚み が決まる。気泡は高い表面張力を持つため疎水性と考えられ, 疎水性相互作用が合一の頻度を高める。界面 活性剂濃度が低くなると, 気泡の踈水力が合一で重要な役割を担い, それが高くなると界面活性剂の表面濃 度勾配による膜弾性が重要となる。本稿では, 水平膜と垂直膜を用いた界面活性剂の単一液膜物性を, 流体 力学扔よび平衡状態解析から明らかにした膜研究を紹介する。応用事例としては, 泡膜安定化に用いられる 種々の添加剤の機能をまとめた。

\begin{abstract}
Stability factors of surfactant foam film are determined by several physical conditions depending on the thickness. Major driving forces in the drainage process are gravity, capillary pressure and surface tension, and the equilibrium film thickness is observed with a balance between the capillary pressure and the disjoining pressure. For a thick foam film, drainage progresses according to the hydrodynamic properties of the solution. Thermal fluctuation would occur during the drainage process, and a black film is finally formed after vigorous fluctuation. For a thin foam film, effects of the disjoining pressure, which can be expressed as the sum of the electrostatic double-layer force and the van der Waals force, would determine the foam film thickness. An air bubble in water would be considered hydrophobic by virtue of its high interfacial tension, thus raising the possibility of bubble coalescence. At the low concentration of surfactant, hydrophobic force plays an important role in bubble coalescence, while film elasticity is important at higher concentrations. The aim of this article is to review the research of single foam films from hydrodynamic and equilibrium points of view with using both horizontal and perpendicular foam film techniques. The effects of additives for foam film stabilization are then described.
\end{abstract}

1 はじめに

泡膜は厚み方向がコロイド次元（1～100 nm）の大き さとなった液膜である。液体薄膜の研究からは, その厚

連絡者：田村隆光

E-mail : tmr-3378@lion.co.jp
みに即した挙動が捉えられることから, 泡立ち, 洗浄, 乳化をコントロールする基本情報が与えられる。界面化 学の分野では, 粒子を自在に並べる技術が急速に進歩 し，自己組織化や非平衡状態を前提に高度の機能設計が なされている。その粒子の配列の解析には, 種々の液膜 の状態観察法が適用されている。ナノコロイドなど粒子 
が微細化すると表面エネルギーが非常に大きくなること から，そのサイズに対応した液膜状態を捉える必要がお こる。たとえば，筆者の研究の場である洗浄技術でみた 場合, Table 1 の概念図に示すように, 対象污れの微細 化にともない，污れの除去手段も大きく変化する。皮脂 などマクロな污れの場合，その付着力は基質との界面を 構成する物質の分子間力となり, その界面エネルギーを 減少させるために界面活性郕が利用される。一方，污れ が微細化あるいは分子で付着するとなると, 表面エネル ギーが増加するため基質に対する付着力が極めて大きく なる。そうなると，もはや界面化学的除去は困難とな り, 研磨による物理力あるいは配位反応や化学分解によ る污れの分子次元での除去が必要となる。すなわち, ターゲットサイズの変化にともない機能を発揮させるた めの, 物理的, 化学的要素に大きな変化が現れることと なる。

泡膜においても，膜厚みに応じてその安定性を支配す る主因子が変化することとなる ${ }^{1)}$ 。単一泡膜は容易に現 象をモデル化できることから広く利用されてきた。直接 観察をすると，Fig. 1 に示すように，気体の間の液膜 （ラメラ）に水が豊富にある厚い状態が, 重力による流 下やキャピラリー圧（液面の曲率により生じるラメラ中 での圧力差）による吸引により薄化が起こる2)。その過 程で熱ゆらぎが観測され，これが激しくなると局所的に 液膜の両面が接触して黒膜が形成される。ただし, 液膜 の熱ゆらぎの成長速度よりも, 薄くなる排液プロセスが 速まると液膜の崩壊が起こる。光を透過し表面からの反 射が弱いため黒膜と呼ばれるが，平衡状態の違いによ り, 通常黒膜 (Common Black Film : CBF) とニュート ン黒膜 (Newton Black Film：NBF）に分けられる。

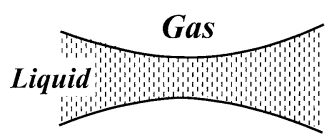

液膜の相互接近

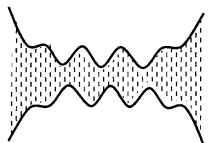

熱ゆらぎ

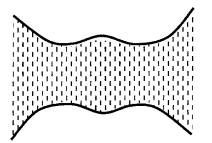

dimple形成

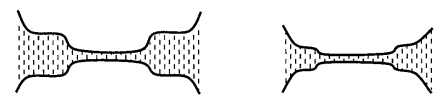

黒膜形成 $\begin{array}{cc}\text { Common Black Film } & \text { Newton Black Film } \\ 5 \sim 20 \mathrm{~nm} & <5 \mathrm{~nm}\end{array}$

Fig. 1 泡膜の薄化過程の挙動
$\mathrm{CBF}$ の厚さは $10 \sim 100 \mathrm{~nm}$ の範囲にあり，厚みは古典的 な DLVO 理論に従ってコントロールされる。一方, $\mathrm{NBF}$ は, 電解質添加による電気二重層の縮退や外圧に よる圧縮で形成される厚さは $4 \sim 10 \mathrm{~nm}$ の膜である。こ のような，一連の液膜の薄化過程には，液膜の垂直方向 にはたらく分離圧と総称される表面力や，流れにともな う粘弾性などが複雑にからみ，その安定性が決定され る。本稿では，複雑な液膜の安定化について，従来まで 調べられてきた単一液膜に関する基本的理解を，筆者ら の行った垂直膜の安定性の知見を含め紹介する。また応 用事例としては，泡膜安定化に用いられる種々の添加剤 の機能をまとめた。

\section{2 薄膜の測定法}

泡膜の安定性を実験的に調べる手法に関しては，多く の総説で紹介されている ${ }^{3-5)}$ 。最も簡単な泡膜の薄化挙動 の観察手法は，フレームなどを引き上げて作った液膜 や，キャピラリーから発生させたシャボン玉の干渉縞を 観測するものであるが，定性的な状態観察であることか

Table 1 対象污れのサイズと洗浄技術

\begin{tabular}{|c|c|c|c|c|c|}
\hline $\begin{array}{l}1000 \mu \mathrm{m} \\
(1 \mathrm{~mm})\end{array}$ & 污れのカ & 素材 & 污れの洗浄技術 & 家庭品分野 & 工業分野 \\
\hline$-10 \mu \mathrm{m}$ & 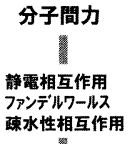 & 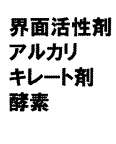 & $\begin{array}{c}\text { 乳化 } \\
\text { 分散 } \\
\text { ローリグアッブ }\end{array}$ & 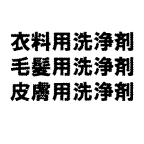 & $\begin{array}{l}\text { 鉄鋼洗浄 } \\
\text { 輪送機器 } \\
\text { 織維 } \\
\text { 紙パルフフ } \\
\text { 食品 }\end{array}$ \\
\hline \begin{tabular}{c|cc}
$1000 \mathrm{~nm}$ \\
$(1 \mu \mathrm{m})$ \\
$100 \mathrm{~nm}$ \\
$\begin{array}{c}1 \\
\text { 組織体 }\end{array}$
\end{tabular} & & 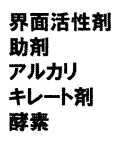 & $\begin{array}{c}\text { 可溶化 } \\
\text { マイクロルション }\end{array}$ & $\begin{array}{l}\text { 台所用洗浄削 } \\
\text { 住居用洗浄绪 } \\
\text { 雷磿き }\end{array}$ & $\begin{array}{l}\text { 自動車部品 } \\
\text { 液晶パネル } \\
\text { 光学部品 }\end{array}$ \\
\hline $\begin{array}{l}10 \mathrm{~nm} \quad \text { 十/污れ } \\
\text { 分子集合体(薄瞙·溦粒子) } \\
1 \mathrm{~nm}\end{array}$ & $\begin{array}{l}\text { 共有結合 } \\
\text { 金属結合 } \\
\text { 配位力 }\end{array}$ & $\begin{array}{l}\text { 研磨柆子 } \\
\text { キレート刘 } \\
\text { 酸 } \\
\text { アルカリ }\end{array}$ & $\begin{array}{l}\text { 微細研磨 } \\
\text { 配位化学 } \\
\text { 研磨(CMP) }\end{array}$ & $\begin{array}{l}\text { クレシザー } \\
\text { 洗浄機用洗削 }\end{array}$ & $\begin{array}{l}\text { ハードディスク } \\
\text { ウエハ }\end{array}$ \\
\hline - $0.1 \mathrm{~nm}$ & 原子間力 & $\begin{array}{l}\text { 活性喠 } \\
\left(\mathrm{H}_{2} \mathrm{O}_{2}, \mathrm{O}_{3}\right) \\
\text { ラジカル } \\
(\mathrm{OH} \cdot)\end{array}$ & $\begin{array}{l}\text { 酸化還元 } \\
\text { 化学反庶( CMP) }\end{array}$ & $\begin{array}{l}\text { 漂白刘 } \\
\text { 除菌 } \\
\text { 消奥都 }\end{array}$ & $\begin{array}{l}\text { 半導体 } \\
\text { 精密洗浄 }\end{array}$ \\
\hline
\end{tabular}


ら, 水平膜 ${ }^{6-11)}$ や垂直膜 ${ }^{12-17)}$ による定量的解析法を利用 して研究することとなる。円形の水平膜が Derjaguin に より提案され，その後 Schledkoらに利用されてきた。 液膜の厚みの直接測定は, Fig. 2 に示すような装置で, 分離圧を膜外からの圧力でキャピラリー圧をバランスさ せて測定を行う。接触角の同時測定を行うことにより， 水平膜の排液挙動を詳細に捉えることができる ${ }^{18)}$ 。

一方, 垂直膜実験は, フレームを引き上げて泡膜を形 成し行われる。主な測定法としては, 光の干涉法, FT-IR 法，ラマン散乱法およびX 線回折法などがある。 筆者らは FT-IR 法でラメラの水のコア厚み $(\mathrm{d} 2)$ を, Fig. 3 のようなセルをビームライン中に設置して測定し ている ${ }^{19)}$ 。垂直多孔質ガラスの中央部に赤外光が通過す るもので, $3450 \mathrm{~cm}^{-1}$ の水分子の $\mathrm{OH}$ 伸縮振動の吸光係

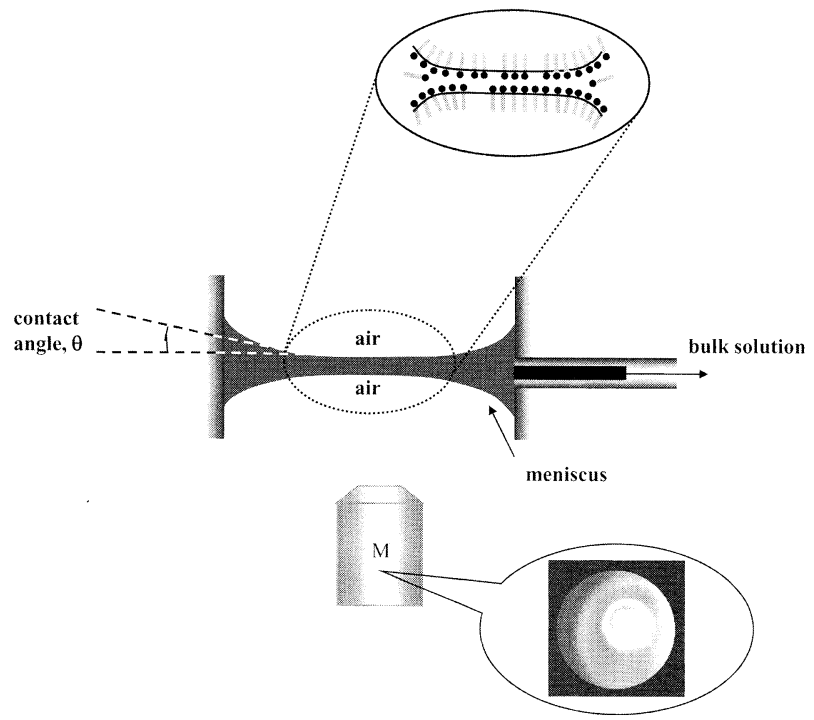

Fig. 2 水平液膜の膜厚みの観測装置

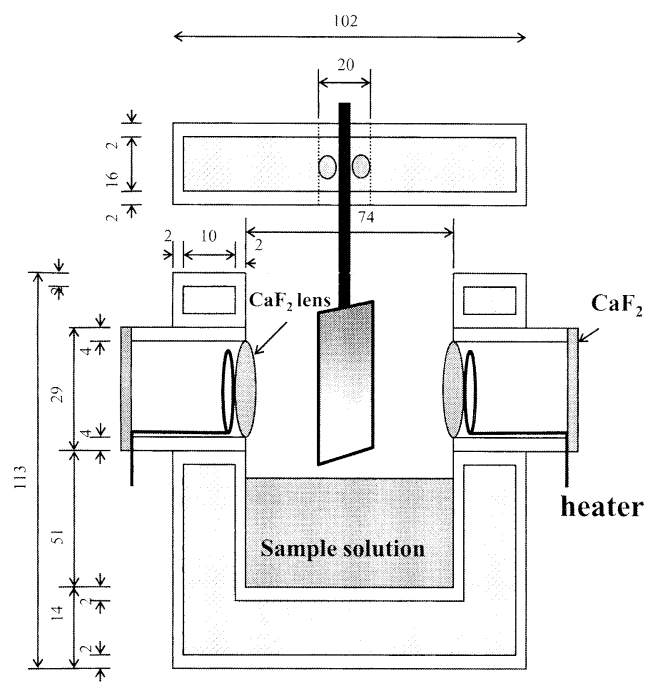

単位: mm

Fig. 3 垂直液膜の膜厚みの観測装置
数を用いて厚みに換算するものである。

\section{3 薄膜の崩壊メカニズム}

\section{$3 \cdot 1$ 分離圧と平衡液膜厚み}

泡膜の状態は種々の物理的エネルギーのバランスによ り決まり，膜厚さに依存してそれを維持する安定化因子 が変化するため, 平衡と非平衡の観点から解説を進め る。すなわち, 圧力や温度など束一性の因子を固定すれ ば，泡膜は平衡状態となるが，そこにいたるまでの過程 は粘弾性の関わる動力学的過程となる。まず平衡膜厚さ に関わる因子を考えてゆく。水平膜の場合，排液の駆動 力はキャピラリー圧であり，排液はキャピラリー圧が泡 膜の分離圧とつりあったとき止まり，平衡の膜厚みが示 される。一般的に分離圧（П）は, 電気二重層反発力 $\left(\Pi_{\mathrm{el}}\right)$ とファンデルワールス引力 $\left(\Pi_{\mathrm{vw}}\right)$ との合算によ り決まる。Derjaguinによる分離圧等温線 (h) として 泡膜への適用がなされ, Fig. 4 に電解質溶液におけるそ の概念図を示す ${ }^{20)}$ 。DLVO 理論によれば， $\prod_{\text {max }}$ を超え る手前の距離に第一の極小は存在し CFB が形成され, この圧力障壁を越えることで，第二の極小に到達し NBF が形成される。

表面圧の観点から上記説明がなされているが，Fig. 5

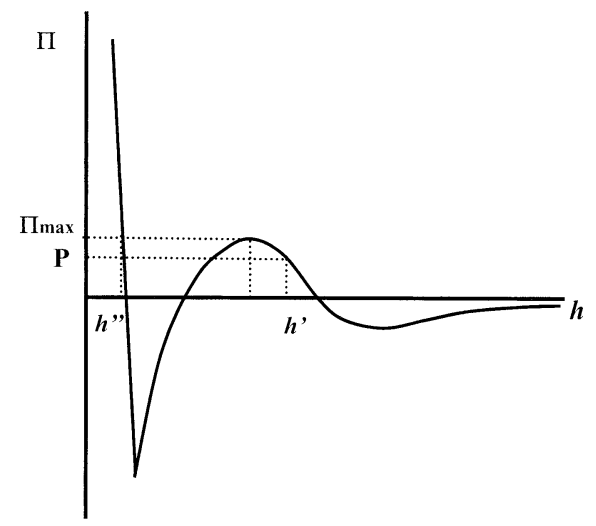

Fig. 4 泡膜の分離压等温線の概念図

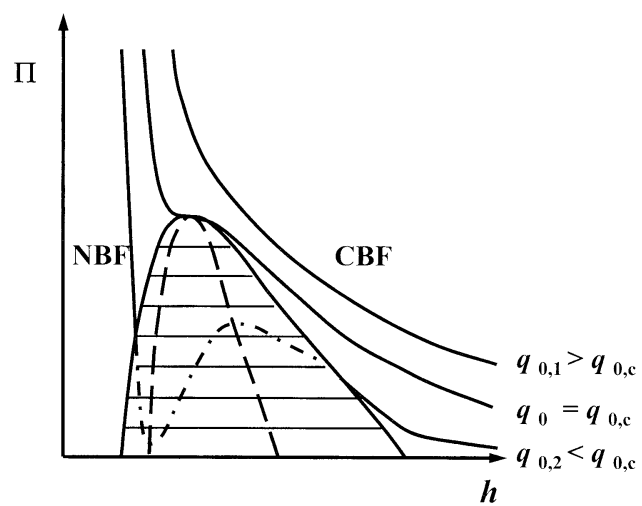

Fig. 5 泡膜の薄化過程の挙動 
に示すように泡膜の П-h 曲線を $\mathrm{p}-\mathrm{V}$ 曲線と対比させる 概念も提唱された ${ }^{21)}$ 。静電反発力で安定化された CBF が気相に対応し，NBF は凝縮液体相に対応している。 電荷 $\mathrm{q}$ の大きさが二次元の相転移にいたる臨界点を境 に，それよりも大きい場合 $\mathrm{CBF}$ のままで膜圧を高めて も NBFへの転移が見られないが，それよりも小さい場 合 NBF への転移が進むこととなる。界面活性剂が液膜 表面へ吸着し, 圧力とともに凝縮膜を形成する二次元膜 の相転移の観点からみた解釈である。

重力や圧力により排液が進み， $\mathrm{CBF}$ が形成される領 域になると，古典的な DLVO 理論の適用によるП-h 曲 線の解析が可能となる ${ }^{22)}$ 。すなわち, 主にイオン性界面 活性剤の泡膜において, DLVO 理論で記述される分離圧 は, 電気二重層反発力とファンデルワールス引力の和と して表される。

$\Pi=\Pi_{\mathrm{el}}+\Pi_{\mathrm{vw}}$

ここで，静電反発力の寄与は（2）式で与えられる。

$\Pi_{\mathrm{el}}=64 \mathrm{C}_{\mathrm{el}} \mathrm{R} \mathrm{T} \tanh ^{2}(\mathrm{ze} \Psi \mathrm{s} / 4 \mathrm{kT}) \exp (-\kappa \mathrm{H})$

ここで $\mathrm{C}_{\mathrm{el}}$ は電解質濃度, $\mathrm{R}$ は気体定数, $\mathrm{T}$ は絶対温 度, $\mathrm{z}$ はイオン価数, $\mathrm{e}$ は電荷, $\Psi_{\mathrm{s}}$ は電気二重層電位, $\mathrm{k}$ はボルッマン定数, $\kappa$ はデバイ長の逆数, そして $\mathrm{H}$ は 二つの荷電面間の距離（泡膜厚み）を示す。

$$
\begin{aligned}
& \text { また, ファンデルワールスカは（3)式で与えられる。 } \\
& \Pi_{\mathrm{vw}}=-\mathrm{A}_{232} / 6 \pi \mathrm{H}^{3}
\end{aligned}
$$

ここで， $\mathrm{A}_{232}$ は水中における気体の Hamaker 定数 で，通常 $10^{-20} \mathrm{~J}$ のオーダーである。

非イオン界面活性剤の場合も, 表面電位の寄与が見積 もられてくるが, 電位発生の起源は, 液膜表面近傍での $\mathrm{OH}^{-}$イオンの吸着によるため, 負の電荷を示すことが定

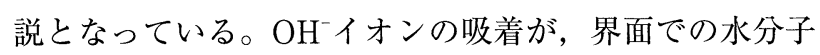
の水素原子と, 強い双極子あるいは水素結合を通じ起こ ることによるものと考えられている。

多くの安定な界面活性剂の泡膜研究は, $\mathrm{CMC}$ 付近の 濃度で行われている。こうした条件下では DLVO 理論 の適用によるП-h 曲線の解析がよくあてはまるが，発 泡現象が関わる多くの実用系では，気泡をそれよりも 2 〜 オーダー低い濃度で発生させ利用する場合も多い。 実際，後述するように崩壊する膜厚みが DLVO 理論か ら予測した曲線よりも, かなり厚い状態で崩壊する。こ れは近年, 低濃度になると液膜の性質は界面活性剂膜と しての表面力の寄与が極めて少なくなり, 溶液の持つさ らなる引力（疎水力： $\Pi_{\mathrm{hb}}$ ）の気泡膜安定性への寄与が 関わってくることが示されてきた ${ }^{23-28)}$ 。すなわち, 界面 活性剂が低濃度の場合, 分散した気泡の安定性は, 遠距 離の疎水力によりコントロールされる疎水コロイドの分 散系と同様に，気泡間の表面力により決まるとするもの
である。水中の気泡は, 気/水界面の高い表面張力から 疎水性と考えることができる。気泡が合一すると，大き な自由エネルギーの獲得がなされるため, 水中での炭化 水素の合一よりもそれが大きい。すなわち, 気泡は炭化 水素系の油よりも疎水的と解釈することで，疎水力が気 泡の合一に重要な役割を示し, 界面活性剤やイオンは疎 水力を減少させ，気泡の安定化を示すと考えるものであ る。たとえば，疎水表面上を奴した液膜は自発的に崩 壊する。その崩壊厚みは固体の疎水性が高まるほど厚く なることからも疎水性が理解される。Craig は電解質水 溶液に扔ける気泡の合一速度を測定し, 電解質濃度の増 加とともに気泡の合一は減少することを報告した ${ }^{29)}$ 。こ れは, 疎水力が電解質濃度の減少につれ増加することを 示唆して扔り，ファンデルワールス力のみでは，気泡同 士が流体力学的力により合一できず, 強い引力の存在を 考える必要がある。

このような観点から，疎水力の寄与を加味すると， (1)式は（4)式のようになる。

$\Pi=\Pi_{\mathrm{el}}+\Pi_{\mathrm{vw}}+\Pi_{\mathrm{hb}}$

蹯水力の寄与は (5) 式で与えられる。

$\Pi_{\mathrm{hb}}=-\mathrm{K}_{232} / 6 \pi \mathrm{H}^{3}$

ここで, $\mathrm{K}_{232}$ は水中における気体の疎水力定数を示 す。

水平膜の実験の場合，平衡においてのキャピラリー圧 $\left(\mathrm{P}_{c}\right)$ は分離圧に等しい。

$\Pi=\mathrm{P}_{\mathrm{c}}$

ここで, $\mathrm{P}_{\mathrm{c}}$ は水平膜のメニスカスでのキャピラリー圧 であり，次式で与えられる。

$\mathrm{P}_{\mathrm{c}}=2 \gamma / \gamma_{\mathrm{c}}$

ここで, $\gamma$ は表面張力, $\gamma_{\mathrm{c}}$ は膜の半径である。これら より（6)式は（8)式で与えられる。

$64 \mathrm{C}_{\mathrm{el}} \mathrm{RT} \tanh ^{2}\left(\mathrm{ze} \Psi_{\mathrm{s}} / 4 \mathrm{kT}\right) \exp \left(-\kappa \mathrm{H}_{\mathrm{e}}\right)-\mathrm{A}_{232} / 6 \pi \mathrm{H}_{\mathrm{e}}{ }^{3}-$ $\mathrm{K}_{232} / 6 \pi \mathrm{H}_{\mathrm{e}}{ }^{3}-2 \gamma / \gamma_{\mathrm{c}}=0$

ここで, $\mathrm{H}_{\mathrm{e}}$ は平衡膜厚みを示す。

さらなる排液により泡膜が薄化するにつれ，臨界膜厚 みに達し崩壊を迎える。これは，泡膜には，常に熱的あ るいは機械的な表面波が生じるため局所的な薄化が抢こ り，その振幅が瞬間的に引力範囲に入ると泡膜の両面が 接触し崩壊に至るからである ${ }^{30)}$ 。界面活性剤が高濃度の 系では，この振動によるエネルギー障壁の消失が崩壊機 構となるが，低濃度の系では疎水力による崩壊機構と認 識されてきている。多くの産業界における泡利用の現場 では，低コストの製剤や処方が日々検討されている。実 用的見地からも，界面活性剤の $\mathrm{CMC}$ 近傍での現象論を 基盤に構築された古典的な理論を低濃度に適用すること の限界を示唆しており，希薄系での新たな視点をもとに 
した泡膜の安定性を考えるコンセプトが提示されたもの と思う。

\section{$3 \cdot 2$ 表面レオロジーと液膜安定性}

泡膜の安定性は表面力（分離圧）のみならず粘弾性の 寄与も考慮する必要がある。界面活性剂単分子膜の表面 レオロジーは安定性に重要な過程を含む。とくに非イオ ン界面活性戍膜に扔いては, 静電反発力の寄与が少ない ことから，泡膜の合一の障壁に膜の強さが関わり，それ が表面レオロジー特性と梁く関係する場合が多い。すな わち，外部かく乱を緩和することのできる表面を持つこ とにより，液膜全体の崩壊を保護するからである。

吸着物質により表面張力が低下している表面に, 短時 間（仮想的に時間ゼロ）に拡張した場合，吸着物質の存 在しない表面が現れる。そのため, 表面張力は増大し, 拡張しない表面との間に張力差 (Gibbs 弾性) が発生す る。液体内部や側方からの分子拡散により，張力差を回 復するため時間依存弾性とも呼ばれる Marangoni 効果 が働く。これにより，液膜には薄化による崩壊に逆らう カがはたらき, 液面のマクロなゆらぎ現象などを引き起 こす。

表面レオロジーと膜の安定性に対しては, 以下のよう な定量的解析がなされている ${ }^{3)}$ 。薄膜の崩壊は, 膜の部 分的拡張にともなう局所的な薄化が起源となる。これが 表面張力の差を生み, 表面弹性係数 $\varepsilon$ が表面積 $\mathrm{A}$ の微 少変化と（9）式で示される。

$$
\varepsilon=\mathrm{d} \gamma / \mathrm{d} \ln \mathrm{A}
$$

ここで, $\gamma$ は表面張力を示す。泡膜の薄化の初期過程 では, 厚い液膜の排液がキャピラリー圧によりコント ロールされるが，薄化とともに表面力でコントロールさ れるようになる。すなわち, 泡膜が厚い状態での薄化速 度は次の Reynolds 式により記述される。

$-\mathrm{dH} / \mathrm{dt}=2 \mathrm{H}^{3} \Delta \mathrm{P} / 3 \mu \mathrm{R}_{\mathrm{f}}{ }^{2}$

ここで $\mathrm{t}$ は排液時間, $\mu$ は動粘度, $\mathrm{R}_{\mathrm{f}}$ は膜の半径, $\Delta \mathrm{P}$ は膜薄化の原動力となる。 $\Delta \mathrm{P}$ はキャピラリー圧と分離 圧の差となり，次式で与えられる。

$$
\Delta \mathrm{P}=\mathrm{P}_{\mathrm{c}}-\Pi
$$

一方, 薄化が進み, 表面力のコントロールが主体とな ると, 界面活性剂の膜面での状態が重要となる。すなわ ち, 単分子膜は直接バルクとつながっているので，表面 レオロジー特性は吸脱着過程と密接に関係する。拡張 (圧縮) で, 単分子膜はバルクから (バルクへ) 吸着 （脱着）し平衡状態へ回復する。拡張速度が遅い場合は 速やかに平衡に達するため, 拡張に抵抗する弾性力はは たらかないが $(\varepsilon \sim 0)$ ，それが速い場合の膜面は変形に 対応する時間がなく, 不溶性単分子膜のような挙動をす る。吸着が拡散によりコントロールされるため, 平衡へ
の回復は界面活性剂の濃度にも強く依存する。

この局所的な表面張力の差は, 界面活性剂の表面移動 および拡散過程に依存することから，拡張応力に対する 表面の応答が，周波数のフーリエ変換で示される ${ }^{30-34)}$ 。 拡張粘弾性倸数 $(\varepsilon)$ は周波数依存の複素数として, (12) 式のように実数部分である拡張弾性係数 $\left(\varepsilon_{\mathrm{r}}\right)$ と, 搪張粘性 $\eta$ に関わる虚数部分 $\left(\varepsilon_{i}\right)$ の和で表される。

$$
\varepsilon=\varepsilon_{\mathrm{r}}+\mathrm{i} \varepsilon_{\mathrm{i}}=\varepsilon \mathrm{r}+\mathrm{i} 2 \pi v \eta
$$

これらを実際に求める場合， $\varepsilon$ は表面積 $\mathrm{A}$ の周期的な 振動発生による周波数 $v$ の関数として得られる。すなわ ち，ある周波数 $v$ に扔いて

$$
\mathrm{A}=\mathrm{A}^{0}+\tilde{\mathrm{A}} \sin (2 \pi v \mathrm{t})
$$

ここで $\mathrm{A}^{0}$ は振動前の表面積, $\tilde{A}$ は振動面積の大きさ を示す。同じ周期で表面張力も同調することから，(14） 式が成り立つ。

$$
\gamma=\gamma^{0}+\tilde{\gamma} \sin (2 \pi v \mathrm{t}+\phi)
$$

ここで $\gamma^{0}$ は振動前の表面張力, $\tilde{\gamma}$ は振動表面張力の大 きさ， $\phi$ は周期振動と応答表面張力も同調する。(9) 式 にしたがって, 複素粘弾性は測定可能な量として（15） 式で表される。

$$
\varepsilon=\mathrm{A}^{0}(\tilde{\gamma} / \tilde{\mathrm{A}}) \cos \phi+\mathrm{i} \mathrm{A}^{0}(\tilde{\gamma} / \tilde{\mathrm{A}}) \sin \phi
$$

これらの実測には，周波数領域により異なった測定法 が用いられるが，低周波数領域では滴形張力計を用い， 振動滴（気泡）の形状を Gauss-Laplace 式にフィットさ せ決定する。内部の液体が外部流体との間の表面張力と 密度に依存することに基づき, 理論値とフィッティング するものである。中間の周波数領域ではキャピラリー压 張力計を用い, 滴/泡二相の間の圧力差を, 滴／泡の体 積変化を通じて測定する。界面活性剂水溶液の系では, $\varepsilon_{\mathrm{r}}$ は周波数とともに増加する一方， $\varepsilon_{\mathrm{i}}$ は極大を示す。こ れは, $\varepsilon_{\mathrm{i}}$ 值の最大周波数は, 弾性率の最大変化率を示す 周波数に対応しているためである。低周波数（１ Hz) において, 界面活性剤濃度が高いほど表面弾性は小さ く, 高周波数では逆となる。このため, 低周波数では, 膜の弾性は主に分子の交換により支配されるため, 濃度 に依存して交換速度も速まることとなる。一方, 高周波 数では, 単分子膜が不溶性膜のように挙動するため, 膜 弾性は主に表面過剩濃度により決まる。したがって, バ ルク濃度や表面過剩濃度が高いほど, 膜弾性は高いこと となる。

\section{4 界面活性剤の泡膜研究}

\section{$4 \cdot 1$ イオン性界面活性剤の水平膜}

$4 \cdot 1 \cdot 1$ 水平膜の平衡論的解析

イオン性界面活性剂の液体自由膜の分離圧等温線は, SDSに打いて多く報告されてきたが，代表的な報告は， 


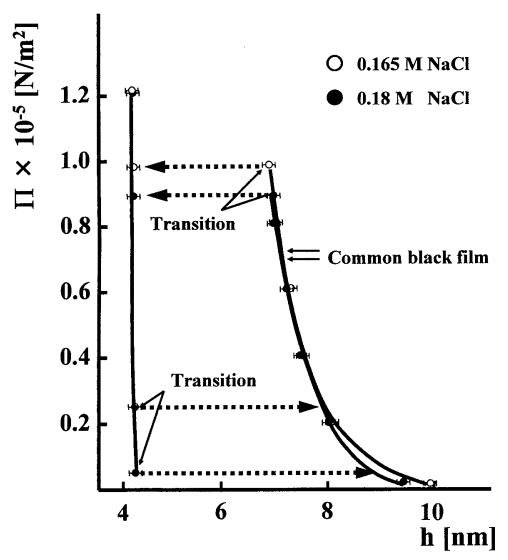

Fig. 6 SDS $\left(10^{-3} \mathrm{M}\right)$ の分離圧等温線

Exerowa, D. and Kashchiev, Contemp. Phys., 27, 429 (1986)

Exerowa らによる多孔質水平セルによる直接観察があ $る^{20)}$ 。 $1 \mathrm{mM}-\mathrm{SDS}$ の П-h 曲線において, $\mathrm{NaCl}$ 濃度 $\left(\mathrm{C}_{\mathrm{NaCl}}\right)$ が $0.15 \mathrm{M}$ 以下では圧力で薄化させると膜は崩壞 するが，高い $\mathrm{C}_{\mathrm{NaCl}}$ において，Fig. 6 に示すように液膜の 薄化により, 通常液膜から $\mathrm{CBF}$ や $\mathrm{NBF}$ への転移が観測 されるようになる。転移の膜厚みは $7.1 \mathrm{~nm}$ で $\mathrm{C}_{\mathrm{NaCl}}$ に依 存することはなかったが，転移する圧力は $\mathrm{C}_{\mathrm{NaCl}}$ が高ま るにつれ低下することから，分離圧のエネルギー障壁が 低下することを示唆した。また， $\mathrm{C}_{\mathrm{NaCl}}$ が $0.165 \sim 0.2 \mathrm{M}$ の範囲内では, 液膜への加圧により $\mathrm{CBF}$ から $\mathrm{NBF} へ の$ 転移が起こるとともに，減圧により NBF から CBFへの 逆転移ヒステリシスが観測される。このような基本的な 挙動は, DLVO 理論による定性的理解はできるものの, 実験結果の定量的説明が難かしかった。すなわち, DLVO 理論からのシミュレーション曲線が実測值のいつ も右側に位置することから，h が薄い領域の反発力を低 く見積もりすぎるといった解釈がなされた。

こうした知見は, $\mathrm{CMC}$ 近傍といった界面活性剤高濃 度系の泡膜挙動を, 分離圧からのアプローチにより概ね 解釈するものである。しかし，前項で述べたように泡を

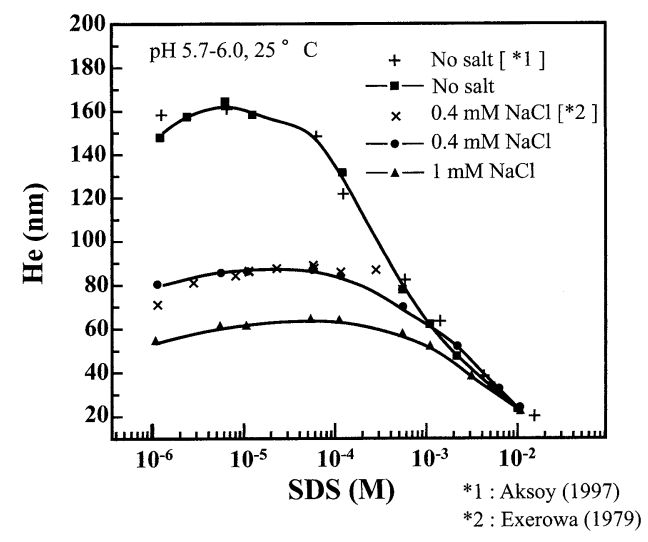

Fig. 7 SDS 濃度と平衡膜厚みの関係

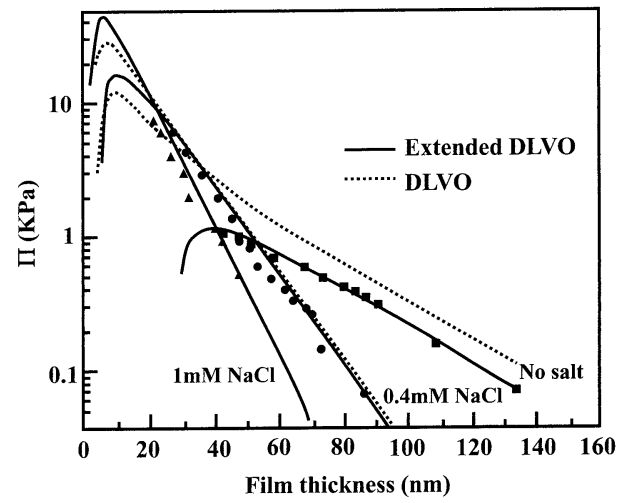

Fig. $8 \operatorname{SDS}\left(10^{-4} \mathrm{M}\right)$ 液膜の分離圧等温線

利用する実用系では CMC のかなり下での使用もなされ ることから, 希薄系での液膜の安定性に抢ける疎水力 （引力）の役割を加味したアプローチが提案されてき た ${ }^{28)}$ 。Fig. 7 にSDS 濃度に対する平衡膜厚み $\left(\mathrm{H}_{\mathrm{e}}\right)$ を， 種々の $\mathrm{C}_{\mathrm{NaCl}}$ で測定して得られた結果を示す。高濃度領 域での $\mathrm{H}_{\mathrm{e}}$ の減少はSDS 自身によりもたらされたイオン 強度による電気二重層の縮退によるものである。一方, SDS 低濃度領域のわずかな $\mathrm{H}_{\mathrm{e}}$ の上昇は, イオン強度が 優勢になるよりも前の $10^{-6} \mathrm{M}$ 領域で観測される。Exerowa らはこれが表面電位の上昇によるものとしたが, Yoon らはSDS 濃度の増加にともなう疎水力の減少の寄 与を示唆した。疎水力の存在は $\mathrm{H}_{\mathrm{e}}$ の減少を招くので, $\mathrm{SDS}$ 濃度の増加につれたその減少は $\mathrm{H}_{\mathrm{e}}$ の増加を招くこ ととなる。

これを検証するため， П-h曲線に抢ける DLVO 理論 との近似を考察した結果を Fig. 8 に示す ${ }^{24)} 。 \mathrm{C}_{\mathrm{NaCl}}=0$ の 系では $1.1 \mathrm{kPa} て ゙ ~ 43 \mathrm{~nm}$ で膜崩壊が起こり, 崩壊膜厚み が DLVO 理論から予測した曲線よりもかなり厚い状態 であった。これを，(4)式で示した疎水力を加味した拡 張 DLVO 理論式において, $\Psi \mathrm{s}=-114.3 \mathrm{mV}, \mathrm{A}_{232}=$ $3.7 \times 10^{-20} \mathrm{~J}, \mathrm{~K}_{232}=2.33 \times 10^{-18} \mathrm{~J}, \kappa=30.4 \mathrm{~nm}$ とするこ とにより，実測值とよくフィットするようになる。ま た, $\mathrm{C}_{\mathrm{NaCl}}=0.4 \mathrm{mM}$ の系では $6 \mathrm{kPa}$ で崩壊するが, 理論 曲線との差はわずかである。さらに, $\mathrm{C}_{\mathrm{NaCl}}=1 \mathrm{mM}$ の系

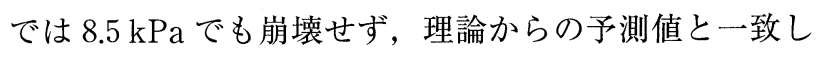
た。これは, $\mathrm{NaCl}$ 添加による疎水力の滅少が寄与した ため, 理論と実測值のずれがなくなってきためで, 疎水 力の存在を示唆している。

\section{$4 \cdot 1 \cdot 2$ 水平膜の動力学的解析}

水平膜の研究において, 平衡膜状態に至るまでの動力 学的挙動も解析されている。泡膜の寿命は排液と崩壊に よりコントロールされ, 水平膜においては, 排液の主体 が両端にできるプラトーボーダーの曲率により生じる キャピラリー圧と表面張力となる。初期の泡膜の薄化は 


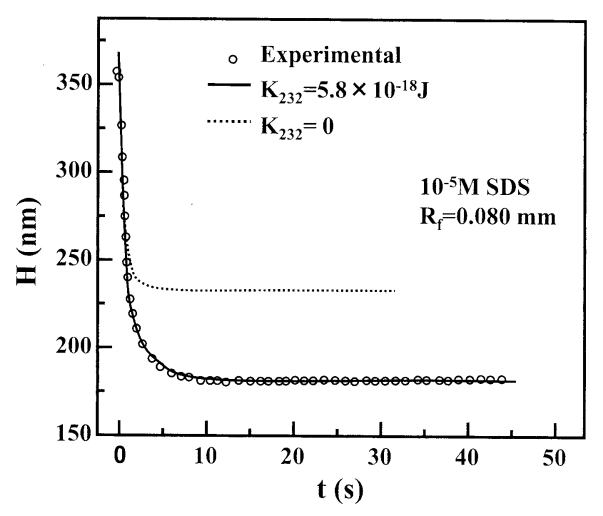

Fig. $9 \operatorname{SDS}\left(10^{-5} \mathrm{M}\right)$ 液膜の薄化の動力学

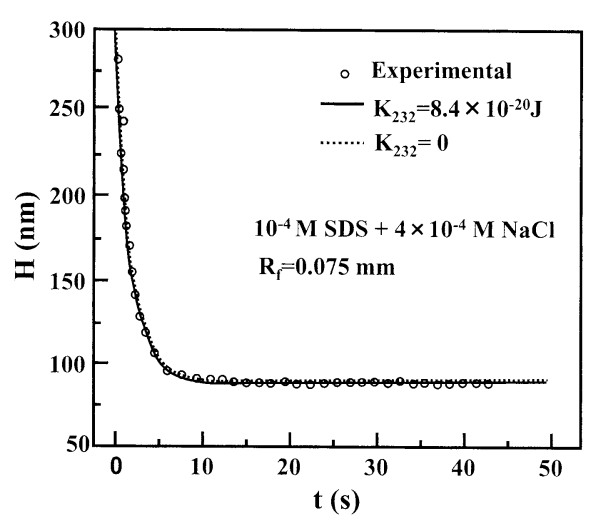

Fig. $10 \mathrm{SDS}\left(10^{-4} \mathrm{M}\right)$ の $\mathrm{NaCl}\left(4 \times 10^{-4} \mathrm{M}\right)$ を含む液膜の薄化の 動力学

速く, 膜の薄化速度は（10）式で解析できる。これは, 初期の膜があまりに厚いため表面力の影響が無視でき， 薄化の原動力がキャピラリー圧に支配されるためであ る。排液の動力学解析として, $\mathrm{NaCl}$ の添加の有無にお ける水平膜厚みの時間変化を測定した結果を Fig. 9, Fig. 10 に示すが，いずれの系も初期の液膜は非常に厚い が, 膜厚みが $250 \mathrm{~nm}$ 以下になると表面力の薄化への影 響が現れる ${ }^{26)}$ 。 $\mathrm{NaCl}$ を添加しない系（Fig. 9）で, Reynols 式に疎水力の寄与を考慮せず，(1)式の古典的 DLVO 理論により与えられるПを用いると, 点線のよう に実測值とおおきなずれが生じる。これを，(8)式の拡 張 DLVO 理論に扔いて, $\Psi_{\mathrm{s}}=-92 \mathrm{mV}, \mathrm{A}_{232}=3.7 \times$ $10^{-20} \mathrm{~J}, \mathrm{~K}_{232}=5.8 \times 10^{-18} \mathrm{~J}$ をあはめたПを用いた Reynols 式は, 実測値との非常に良いフィットが得られ た。一方， $\mathrm{NaCl}$ を添加した系（Fig. 10）では，(1)式 で, $\Psi_{\mathrm{s}}=-110 \mathrm{mV}, \mathrm{A}_{232}=3.7 \times 10^{-20} \mathrm{~J}, \mathrm{~K}_{232}=0$ をあて はめたПを用いるだけでも，実測值とのフィットが得ら れた。すなわち, 界面活性片と無機イオンにより疎水力 が弱められたことを示唆している。

\section{$4 \cdot 2$ 非イオン界面活性剤の水平膜}

\section{$4 \cdot 2 \cdot 1$ 水平膜の平衡論的解析}

イオン性界面活性剂の場合, 気／液界面での二重層電
位（ $\Psi \mathrm{s}$ ）をGibbs 吸着等温式を用いて電荷種の吸着密 度から計算できるため, 分離圧の寄与を決めることがで きる。しかし，非イオン界面活性剤では，電気二重層電 位を決定する信頼できる方法がないため, 電解質の添加 によりその反発力を抑えて実験を進めることとなる。

SDS と同様に代表的な報告は, Exerowa らによる典 型的な非イオン性界面活性剛の報告がある ${ }^{41)} 。 0.5 \mathrm{mM}$ C10E4（テトラオキシエチレンデシルエーテル）で安定 化された膜に対する $\mathrm{C}_{\mathrm{KCl}}$ と平衡膜厚み $(\mathrm{h})$ の測定結果 は，黒膜形成がおこる濃度まで， $\mathrm{C}_{\mathrm{KCl}}$ の増加とともに h は減少し一定となる傾向が見られ， $\mathrm{C}_{\mathrm{KCl}}=0.5 \mathrm{M}$ まで $\mathrm{h}$ の変化がみられなかった。Fig. $11 に 0.3 \mathrm{mM} \mathrm{KCl}$ におけ るП-h 曲線を示すが，hの減少により $11 \mathrm{~nm}$ の CBF が 形成するとともに, $6.5 \mathrm{~nm}$ の NBFへの転移を示した。 この NBF は圧力増加においてもあまり変化がみられず, SDS 膜でみられたヒステリシスは観測されなかった。

また, 泡膜の厚みには電解質の影響も大きく, Müller らにより C12En（ $\mathrm{n}=7 \sim 56)$ の平衡液膜厚みにおよぼす 無機塩の添加効果が報告された ${ }^{42)}$ 。これらの系では, $\mathrm{KCl}$ 添加にともない膜厚みが急激に減少するなかで, 電 気二重層形成による液膜厚みが増す臨界濃度域があるこ とを示した。このピーク位置は親水部分の $\mathrm{EO}$ 鎖長の増

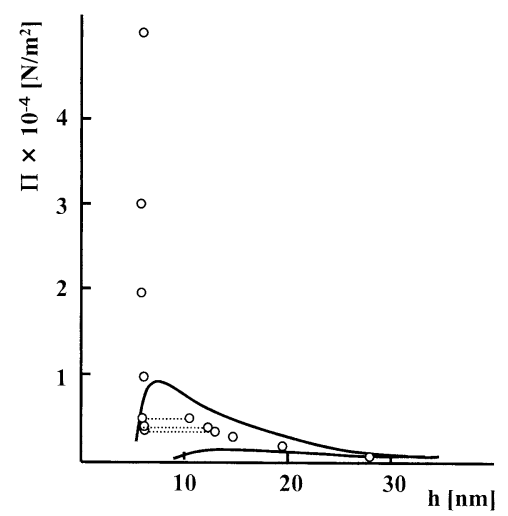

Fig. $11 \mathrm{C} 10 \mathrm{E} 4\left(5 \times 10^{-4} \mathrm{M}\right)$ の $\mathrm{KCl}\left(3 \times 10^{-4} \mathrm{M}\right)$ を含む液膜の分 離圧等温線

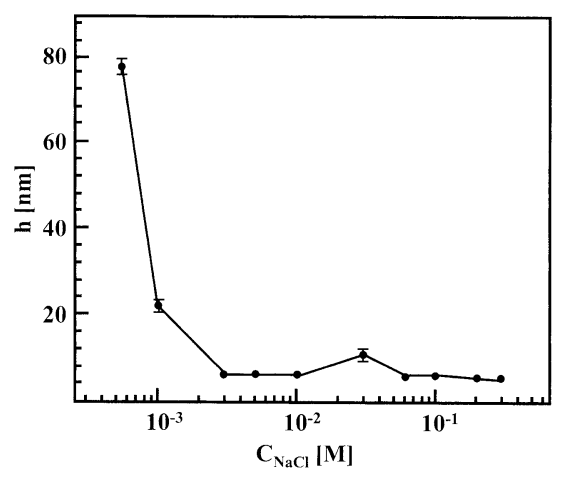

Fig. $126 \times 10^{-4} \mathrm{M} \mathrm{C10} 55$ の $\mathrm{NaCl}$ 濃度と泡膜厚みの関係 
加とともに高塩濃度側へシフトすることが報告された。 最近でも，Krastev らが，Fig. 12 に示す 0.6 mM-C10E5 の平衡泡膜厚みにおよぼす $\mathrm{C}_{\mathrm{NaCl}}$ の影響を報告した ${ }^{18)}$ 。 低塩濃度域では, 22〜 78 nm の厚い泡膜を形成するが, 塩濃度が高まると $6 \mathrm{~nm}$ ほどの NBF を形成することが わかった。塩濃度に依存した膜の薄化は, 非イオン系で も電気二重層の存在を示唆するもので, DLVO 理論によ る解析による表面電位は $39 \mathrm{mV}$ と見積もられた。表面 電位の起源は一般に, $\mathrm{OH}^{-}$イオンの気／液界面への吸着 によるものとされているが，これだけではNBF の安定 性を保つに十分な自由エネルギーとはならず，強い反発 力は $\mathrm{EO}$ 鎖の立体反発力によるものと考えられている ${ }^{43)}$ 。

\section{$4 \cdot 2 \cdot 2$ 水平膜の動力学的解析}

動力学的挙動の解析は, Ravera らが非イオン泡膜の 安定性において, 分離圧の解析とあわせた表面レオロ ジーからのアプローチを試みた。泡膜の安定性は, 泡膜 の寿命ではなく, 泡膜に加えた最大圧力と捉えている。 Fig. 13 に, C10E4の濃度を変えたП-h 曲線を示すが, 濃度を高めるにつれ膜の薄化と崩壊圧の上昇がみられ る ${ }^{31)}$ 。図中の直線は, 表面電荷密度を $1.17 \mathrm{mCm}^{-2}$ とし たDLVO 理論曲線を示すが，低濃度の 4 つの系はすべ てこの曲線に近似されるが, 泡膜の安定性が濃度ととも に大きく向上している。さらに, 高濃度では $0.95 \mathrm{mCm}^{-2}$ と表面電荷密度は減少しているにもかかわらず泡膜が安 定化することから，C10E4 膜の安定性は表面力だけでは 説明できない。

一方, Fig. 14 に 10E4 泡膜の表面弾性係数 $\left(\varepsilon_{\mathrm{r}}\right)$ の周 波数依存性を示すが, 低周波数（１ Hz）領域では, C
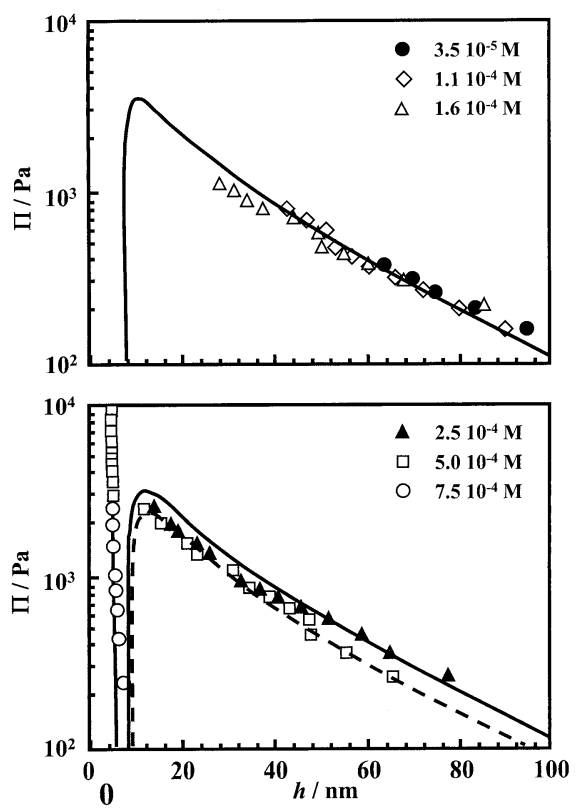

Fig. 13 各種濃度における C10E4 の分離圧等温度線

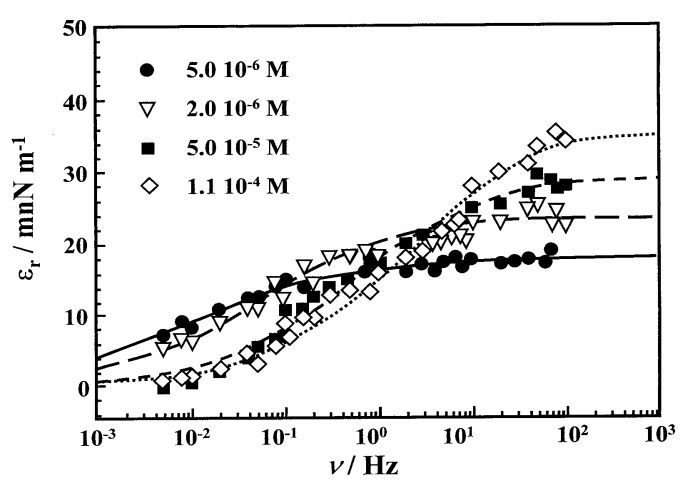

Fig. 14 各種濃度における C10E4 の周波数に対する拡張表面 弾性の実数部分

E. Santini, F. Ravera, M. Ferrari et al., Colloids Surfaces A, 298, 12 (2007)

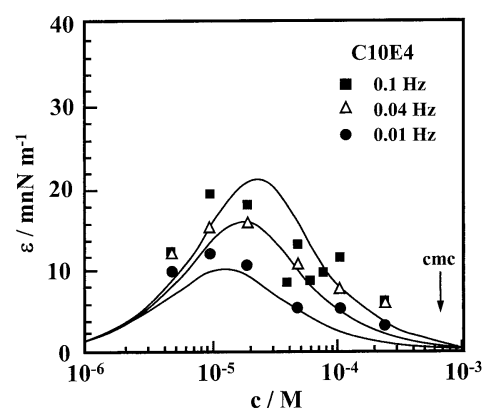

Fig. 15 各周波数における C10E4 拡張表面弾性の濃度依存性

$10 \mathrm{E} 4$ 濃度が高まるにつれ $\varepsilon_{\mathrm{r}}$ は低下するが，高周波数領 域ではそれが向上する ${ }^{31)}$ 。C $10 \mathrm{E} 4$ が $1.1 \times 10^{-4} \mathrm{M}$ から $2.5 \times 10^{-4} \mathrm{M}$ になると膜の崩壊圧が $800 \mathrm{~Pa}$ から $3,000 \mathrm{~Pa}$ に上昇するが，これは高周波領域の弾性率の向上による ものと考えられている。すなわち, 安定な膜には外部か く乱を緩和する表面弾性が必要で，これが崩壊から膜を 保護するため, 崩壊直前の膜にかけられる最大圧と相関 することとなる。

これら界面活性剤単分子膜の表面弾性は, 泡膜の安定 性との相関が得られている。Fig. 15 に $10 \mathrm{E} 4$ の各周波 数における表面拡張弾性の濃度依存性を示すが, 眓中の 実線は（13）式を用いた計算值である ${ }^{32)}$ 。実測値と計算 值との多少のずれはあるものの, 濃度の増加につれて $\varepsilon$ は極大值を示し，その極大值は周波数が高まるにつれ て，高濃度側へシフトしている。これは，泡膜が拡張し たあと, 低濃度域では表面の吸着平衡への回復速度が遅 すぎ，逆に高濃度域ではそれが速すぎ，いずれも $\varepsilon \rightarrow 0$ となるために, 膜弾性力が最も強く働く濃度が存在する こととなる。また，吸着平衡へ回復する速度が速くて も，周波数が高い場合には表面張力勾配が保てる。その ため高濃度側へのシフトとともに， $\varepsilon$ の絶対值も高まる こととなる。この現象は, $4 \cdot 3 \cdot 3$ に述べる Marangoni 効 果を反映する挙動でもあり，Fig. 15 はそれを表面レオロ 


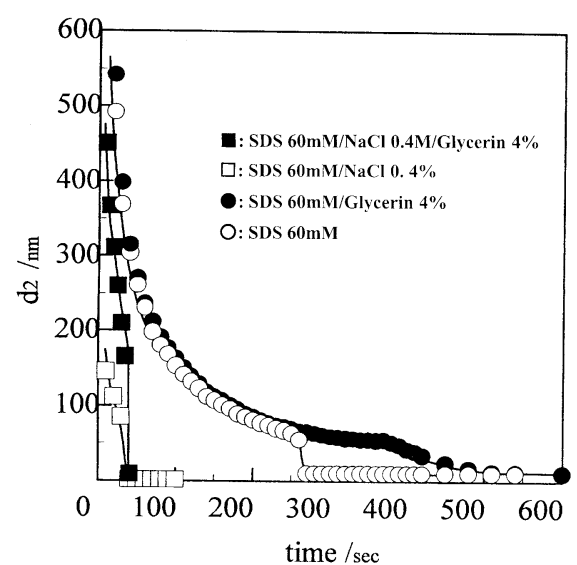

Fig. $16 \mathrm{SDS}(60 \mathrm{mM})$ の垂直液膜の厚み $(\mathrm{d} 2)$ の経時变化にお よぼすグリセリンの影響

ジーの観点から解析したものと考えられる。

\section{$4 \cdot 3$ 垂直膜による解析}

\section{$4 \cdot 3 \cdot 1$ 排液挙動におよぼす表面粘度の効果}

泡膜の排液の過程では, 表面吸着分子膜の拡張やズリ が起こるため, 表面応力が生じる。そのため, $3 \cdot 2 て ゙$ 述 べたように排液は泡膜の表面レオロジー特性に依存する こととなる。膜の薄化におよぼす表面粘度の効果は，多 くの数值的, 実験的アプローチにより研究されてきた。 とくに, Sasaki らによる一連の研究で，表面粘度が泡膜 安定性に関わる重要な因子であることが実験的に検証さ れた ${ }^{45)}$ ささらに, 液膜のレオロジー研究がなされること により，泡膜の安定性との関係が定量的に理解されるよ うになってきた ${ }^{46-49)}$ 。

筆者らも，垂直膜の排液におよぼす表面シェア粘度の 影響を，SDS/ $\mathrm{NaCl} /$ グリセリンからなるモデル膜で調べ た ${ }^{50)}$ 。Fig. 16 に排液曲線の測定結果を示すが，SDS/グ リセリン系の表面シェア粘度は，SDS 単独系に比べ 20\%ほど増加するが， $\mathrm{NaCl}$ の添加で 1/6に減少してい る。グリセリンの添加では排液パターンにほとんど違い はないが，排液がやや遅れるとともに，黒膜への転移が 長時間領域に移行している。また， $\mathrm{NaCl}$ の添加では， 静電反発力により安定化された泡膜であるため，厚い泡 膜条件で排液速度が速まる。しかしながら，いずれの系 で転移した後の黒膜厚みおよび崩壊時の厚みはほぼ等し い。したがって，表面粘度は排液速度を遅らせるもの の，崩壊厚みからみた泡膜の安定性への影響は小さいこ とが示唆された。

\section{$4 \cdot 3 \cdot 2$ 排液挙動におよぼす分離圧の効果}

複雑に入り組んだ泡膜中で液体が流れ落ちてゆく過程 では，重力やキャピラリー圧の作用でプラトー領域に液 体が押し出され薄化が進む。3.5 で述べたように，泡膜 の排液が進行するにつれ，キャピラリー圧以外に膜厚み

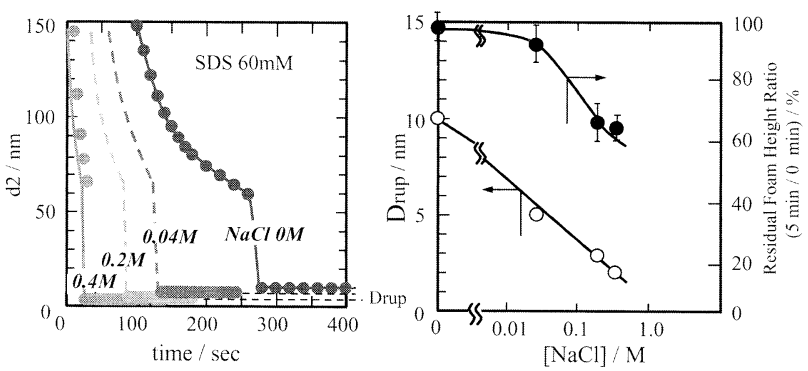

Fig. $17 \mathrm{SDS}(60 \mathrm{mM})$ の垂直液膜の厚み (d2) と泡沫安定性に 掞よぼす $\mathrm{NaCl}$ の影響

に依存してさまざまな力が働くこととなるが，イオン性 界面活性剂の泡膜の安定性には，分離圧（П）の寄与が 大きく，ாは電気二重層の反発力とファンデルワールス カのバランスでコントロールされる。Пは膜表面が十分 に近づいた（<100 nm）場合の反発力となるが，泡膜の 崩壞は表面で生じた機械的あるいは熱ゆらぎが引き金に なるため，分離圧の増加はこのゆらぎで生ずる局所的薄 化に逆らう力となり，崩壊が抑制される。静電反発力に よりもたらされる安定性は, 熱ゆらぎに対する安定化に 最も寄与するが, 膜厚さは界面活性剂溶液の電解質濃度 により変化する。

Fig. 17 左図に， $\mathrm{NaCl}$ 濃度を変化させた $60 \mathrm{mM} \mathrm{SDS}$ の泡膜の排液挙動を調べた結果を示すが，塩濃度に依存 して 2 タイプの SDS 黒膜が観測された ${ }^{50)} 。 \mathrm{CBF}$ は低い 塩濃度 $(<0.1 \mathrm{M})$ で現れ, NBF は高い塩濃度で観測さ れた。純粋な SDS 溶液の泡膜の排液時間は, CBF 形成 まで $250 \mathrm{sec}$ を要するが，静電効果を遮蔽した SDS/0.4 $\mathrm{M} \mathrm{NaCl}$ 系では， $\mathrm{NBF}$ まで $30 \mathrm{sec}$ と非常に短時間で薄化 が起きている。泡沫の安定性におよぼす塩の効果と対比 させると Fig. 17右図のようになる。崩壞する時の膜厚 み $\left(\mathrm{D}_{\text {rup }}\right)$ は純水系では $10 \mathrm{~nm}$ であるが, $\mathrm{NaCl}$ の添加 とともに $2 \mathrm{~nm}$ まで薄化が進んでいる。この結果は, $\mathrm{NaCl}$ により表面電荷が遮蔽され表面間の相互作用エネ ルギーの極小が深まり，それによる強い絞り出し効果が 反映されたものと考えられる。Ross \& Miles 法による 5 分後の泡沫残存率をみると, $\mathrm{NaCl}$ を添加するにつれ減 少するが，高濃度に添加しても $60 \%$ 程度まで減少する にすぎず，消泡を目的とした場合にはその効果は少ない ことを示唆している。

一方，非イオン界面活性剤では静電反発力の寄与が少 ないため，純水系では速やかな排液が見られるが，無機 塩の添加効果を見ると複雑となる。Yamanaka は, 非イ オン界面活性剤の垂直膜の安定性を調べ，無機塩の添加 が液膜の水和構造への影響や拡散電気二重層形成を起こ すことで，黑膜形成を促進あるいは遅延させる場合があ ることを示した ${ }^{13)}$ ここは，4·2で述べたように，水平 

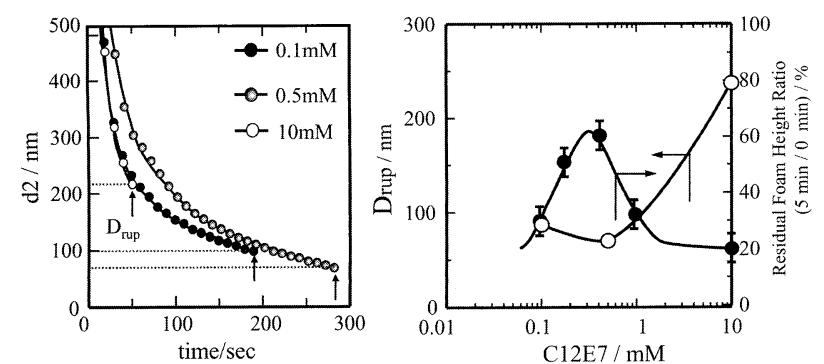

Fig. $18 \mathrm{C} 12 \mathrm{E} 7$ 濃度の垂直液膜の厚み (d2) と泡沫安定性への 影響

膜の研究から, 非イオン界面活性剂において, 無機塩は 水平膜の厚みに対して条件により複雑な影響をすること とも対応するものである。

\subsection{3 排液挙動におよぼす Marangoni 効果}

Marangoni 効果は泡膜安定化に寄与するが，その効果 は界面活性剤の濃度に依存する。表面吸着量が少ない薄 い濃度では，表面張力勾配が取れないため，Marangoni 効果が十分に働かず，濃度が高すぎる場合，その表面吸 着速度が大きいため, 発生した表面張力勾配が即座に消 えるため，やはりその効果は十分に働かないこととな る。したがって，その中間濃度域で Marangoni 効果が最 も強く働くこととなり，泡の安定化が観測される。 $4 \cdot 2$ では表面レオロジーの観点から考察したが，垂直膜の排 液パターンからも裏づけられる。すなわち, Fig. 18 左図 に C12E7 の濃度に対する垂直薄膜の排液曲線を示すが, 崩壊までの排液時間は, $0.5 \mathrm{mM}>0.1 \mathrm{mM}>10 \mathrm{mM}$ の 順に減少している ${ }^{50)}$ 。この排液時間の長さは薄化に逆ら う Marangoni 効果を反映しており，0.5 mM で排液速度 が遅くなるとともに, 泡膜自体の崩壊の厚みも薄くなる まで安定性が向上する。泡の安定性に抢よぼす C12E7 濃度の効果と対比させると Fig. 18右図のようになる。 Ross \& Miles 法による 5 分後の泡沫残存率をみると, $0.5 \mathrm{mM}$ 付近に極大を示し, そこで泡膜崩壊厚みが最も 薄くなっている。濃度が低すぎても高すぎても泡沫が不 安定となり, 排液パターンでみられた Marangoni 効果 が泡沫安定性を反映しているものと考えられる。
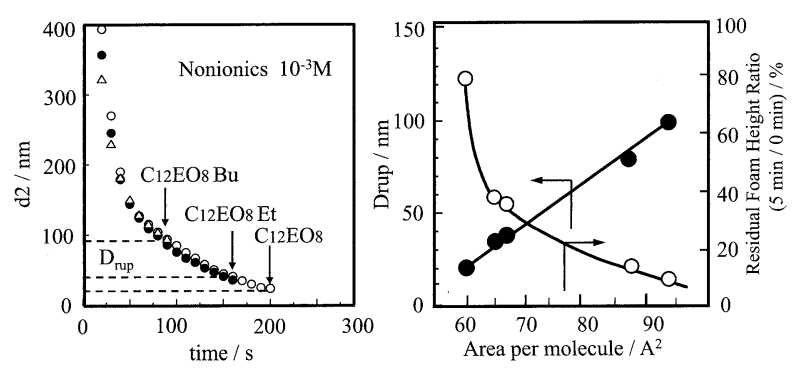

Fig. $19 \mathrm{C} 12 \mathrm{E} 8$ の末端疎水化による垂直液膜の厚み $(\mathrm{d} 2)$ と泡 沫安定性への影響

\subsection{4 排液挙動におよぼす疎水性相互作用の効果}

表面弾性は液体表面を単位面積だけ変化させた場合の 表面張力差でもある。表面弾性は表面張力勾配を生み出 す能力でもあり, 泡膜の安定性を特徵づけるものとな る。高い弾性を持った膜は長い排液時間を持ち, 界面活 性剂の場合はアルキル鎖長とともに増加する傾向を示 す。こうした疎水性相互作用力を, $\mathrm{EO}$ 鎖長とアルキル 鎖長の異なる種々の非イオン界面活性剤の垂直膜安定性 から調べた ${ }^{51)}$ 。Fig. 19 左図に，アルキルエーテル $\mathrm{C} 12 \mathrm{En}(\mathrm{n}=8,22,53)$ および疎水基（エチル，ブチル） で修飾したもの（C12E $8 \mathrm{Et}, \mathrm{C} 12 \mathrm{E} 8 \mathrm{Bu} ）$ の $1 \mathrm{mM}$ 水溶液 を用い垂直泡膜の厚み変化を測定した結果の一部を示 す。 $\mathrm{C} 12 \mathrm{E} 8<\mathrm{C} 12 \mathrm{E} 22 \cong \mathrm{C} 12 \mathrm{E} 8 \mathrm{Et}<\mathrm{C} 12 \mathrm{E} 53<\mathrm{C} 12 \mathrm{E} 8 \mathrm{Bu}$ の 順に $\mathrm{D}_{\mathrm{rup}}$ が増加するが，Fig. 19 右図にそれらの分子占 有面積を指標に，Ross \& Miles 法による 5 分後の泡沫残 存率とともにまとめた。 $\mathrm{D}_{\text {rup }}$ 值は分子占有面積の増加と ともに直線的に増加し，それにともない泡沫安定性が著 しく低下した。たとえば， C12E8Buの $\mathrm{D}_{\text {rup }}$ 值は C12E8 の 5 倍（約 $100 \mathrm{~nm}$ ) の值に達した。泡沫安定性は $\mathrm{C} 12 \mathrm{E} 8$ では 80\%残存するが，C12E8Bu では 10\%まで低 下している。泡膜の吸着膜中の分子間疎水性相互作用 が，排液の過程で数 10１00 nm の厚み領域での垂直膜 の安定性に重要な意味を持つ。分子占有面積の大きな界 面活性剂構造設計をすることにより，低泡化を図ること ができることを示唆している。

\section{5 泡膜安定化剤}

ここまで，主に単一の界面活性剤の泡膜安定性を述べ てきた。実用的見地からみると，利用する界面活性物質 の泡膜は，目標機能に合わせるため種々の添加剤との複 合系が主体となっている。そのため泡膜安定化剤に関す る多くの研究がなされ, Lai らによる総括的解説をもと に概説する ${ }^{52)}$ 。

\section{$5 \cdot 1$ 有機物質}

最も広範に研究されており，実用的に応用されている 片である。その効果は，泡膜に吸着する界面活性剤の密 度を高めることにある。その結果，泡膜は弾性力を増 し, 排液が遅れ安定化する。代表的な剂を以下紹介す る。

\section{$5 \cdot 1 \cdot 1$ 脂肪アルコール・脂肪酸}

ドデシルアルコールはよく知られた安定化剤で，たと えば，Brawnらは，SDSの 0.1\%水溶液の泡寿命は 70 分であるがドデシルアルコールを $0.001 \%$ 添加するだけ で寿命は 350 分と飛躍的に延びることを示した ${ }^{53)}$ 。Fig. 20 に結果を示すが，この効果は多くの研究者も報告し ている ${ }^{54-57)}$ 。排液を著しく遅らせることが明らかとな 


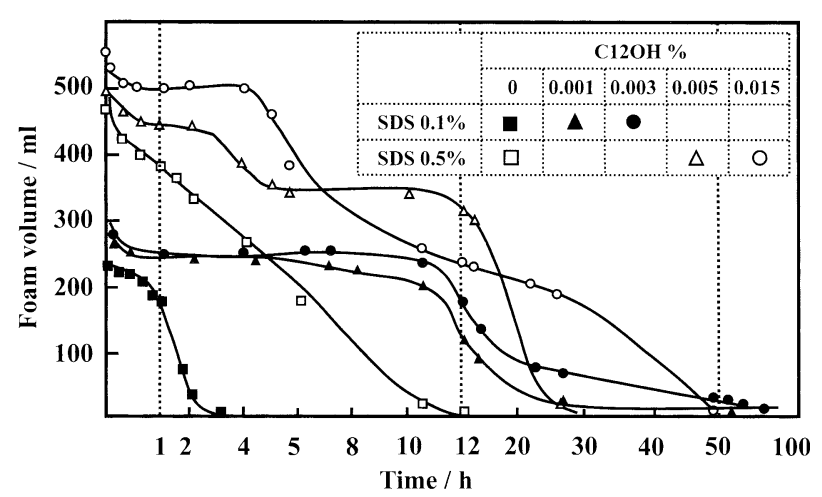

Fig. 20 SDS とドデシルアルコール $(\mathrm{C} 12 \mathrm{OH})$ の混合液の泡寿 命

り，その原因が表面粘度の上昇と考察されている。ま た，界面活性剂水溶液の起泡性は CMC 以上に最大が現 れる傾向にあることから, CMCの低下が起泡性, 安定 性を増すことが報告されている。Sawyer と Fowkes が 行った種々の添加剤の効果から，最も CMC を低下させ る添加剤が最も泡安定性を高めていることがわかる ${ }^{56)}$ さらに, Kung とGoddard は, 分子会合状態を検討し, アルコールとサルフェートが $1: 2$ の複合体の存在を示 唆した ${ }^{57)}$ 。非イオン界面活性剤の排液が速い泡膜におい ても，脂肪アルコールを添加することで極めて排液が遅 くなることが報告された ${ }^{59)}$ 。

一方, 種々の脂肪酸の石けんの泡立ちは $\mathrm{pH}$ に強く依 存している ${ }^{60)}$ 。至適な $\mathrm{pH}$ の存在は, 遊離脂肪酸の重要 な役割を示唆しており, 過脂肪剂との呼び名で皮膚洗浄 剤における泡のきめ細かさをコントロールする効果を示 す。これは, 石けんからできる泡膜が，空気中の炭酸ガ スなどにより脂肪酸の膜となる過程で，一定の組成比か らなるAcid-Soap と呼ばれるイオン対が弱アルカリ領 域で形成されるなど，複雑な現象が関与することによる ものである。

5·1·2 アルカノールアミド・アミンオキシド

シャンプーや台所用洗剤などの実用系で最もよく利用 されてきた素材である。脂肪酸 $(\mathrm{C} 10 \sim \mathrm{C} 16)$ とモノ工 タノールアミン， ジエタノールアミン，イソプロパノー ルアミンの縮合物が一般的である。ジエタノールアミド は水溶性であり，液体洗剂によく用いられ，モノエ夕 ノールアミドとイソプロパノールアミドはハイドロト ロープと一緒に用いられる。1953 年に初めて報告され, アルカノールジエタノールアミドの分子量の影響が報告 された ${ }^{61)}$ 。 $150 \mathrm{ppm}$ 硬度でシャンプーなどの泡立ちを比 較すると, 効果が小さい順に $\mathrm{C} 10<\mathrm{C} 12<\mathrm{C} 14<\mathrm{C} 16<オ$ レイル $<\mathrm{C} 18$ となる。シャンプーの泡立ちからみると， $\mathrm{C} 12$ モノエタノールアミドと C12 イソプロパノールアミ ドは同等であり，C12 ジエ夕ノールアミドより優れてい

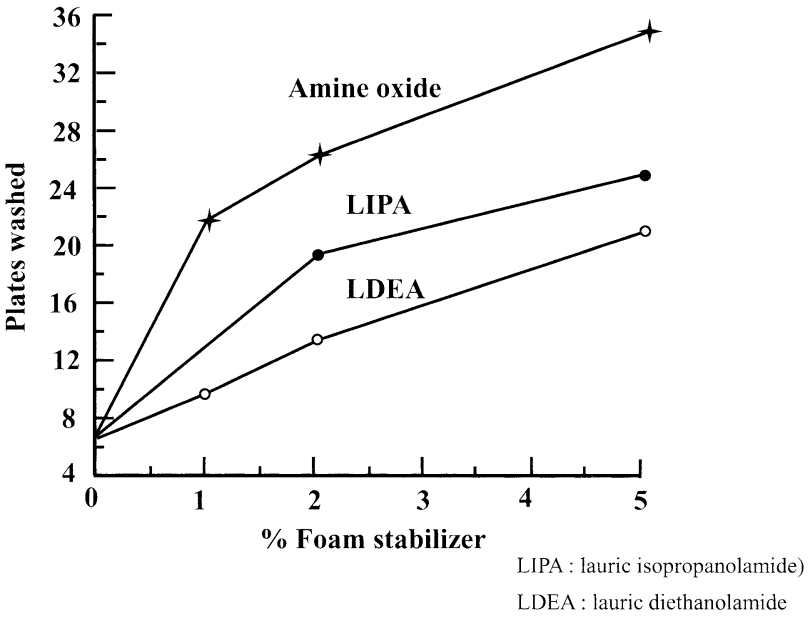

Fig. 21 台所用洗剂の泡安定性（Ca 硬度 300 ppm）

る。Schickらは，アルカノールアミドの効果を CMCの 低下能と関連づけて報告している ${ }^{56)}$ 。

アミンオキシドは従来より界面活性能と殺菌力のある ことが知られている ${ }^{62)}$ 。1956 年に発泡ゴム製品の泡沫安 定化剂としてジメチルドデシルオキシドアミンの特許が 権利化され，液体洗剂の泡安定化剂としてもはじめて用

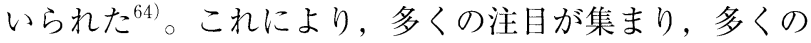
製品に組み込まれた。Malson は，脂肪アミンオキシド をライト系液体洗剂，ヘビー系液体および粉末洗剤の泡 安定化剂への応用研究を行い, Fig. 21 のようにアルカ ノールアミドとの比較を報告した ${ }^{65)}$ 。シャンプーへの応 用は，pH 5.5 以下でアミドは不安定となるが，アミンオ キシドは pH 3.5 でも安定であることから好んで使われ る。最もよく使われてきたものは， N, N-ジメチルドデ シルアミンオキシドと $\mathrm{N}, \mathrm{N}-$ ジメチルミリスチルアミン オキシドである。

安定化の機構について Kolp ら ${ }^{66)}$, Rosen ら ${ }^{67)}$ は独自に 研究し，同一の結論にいたった。すなわち， $\mathrm{RN}\left(\mathrm{CH}_{3}\right)_{2} \mathrm{OH}+$ とアニオン性界面活性剂の強い相互作用をあげ，水素結 合により， $\mathrm{RN}\left(\mathrm{CH}_{3}\right)_{2} \mathrm{OH}+-\mathrm{O}_{3} \mathrm{SR}$ が生成するものとした。 この化合物は，表面に強固に吸着し，密な配向をとるも のと考えられた。

\section{$5 \cdot 2$ 電解質の効果}

電解質はアニオン性界面活性剂の泡膜への安定化効果 を示す。これは，アニオンーカチオン間の静電引力に よって界面活性剤親水基間の反発が緩和され，泡膜が安 定化する。Camp らは，ラウリン酸ナトリウム水溶液の 泡沫安定性に打ける電解質効果を報告した ${ }^{68)}$ 。カチオン 種の濃度およびサイズ，アニオン種のサイズ，およびイ オン種の電荷が大きく影響するとした。リン酸水素二ナ トリウム，ピロリン酸四ナトリウム，トリポリリン酸五 ナトリウムのような嵩高い電解質には, pH 10 での泡沫 
を安定化する効果がある。

また電解質は, 泡膜の両面に形成される界面活性剂吸 着膜間の電荷反発を中和し, 排液を促進した泡膜を不安 定化することもある ${ }^{69)}$ 。電解質は界面活性剤と不溶性の 複合体を形成するとさらに泡膜を不安定化する ${ }^{70-72)}$ 。一 般に電解質は, 非イオン界面活性剂の泡立ち, 安定性に はあまり大きな影響を与えない ${ }^{73)}$ 。

\section{$5 \cdot 3$ 微粒子の効果}

微粒子が泡膜安定化効果を持つことは以前より知られ ている ${ }^{74)}$ 。微粒子の効果は, 泡膜表面で微粒子が密に吸 着することで泡沫中の合一が防げられる。粗粒子を微分 散させることで泡膜安定性が向上することも報告され， たとえば，方鉛鉱を安定化剂として用いた場合，900〜 2,500 メッシュパスの粒子で 1 分の泡沫寿命が，9,000〜 12,000メッシュパスの微粒子では数時間となる。Skyler らは，ドデシルアミン塩酸塩，ABS，ASの泡沫に対し てシリカ，酸化鉄（III）粒子に安定化効果があることを 報告した ${ }^{75)}$ 。また, Tang らは, SDSの泡沫の安定性に およぼすシリカの効果を報告し，その添加量が増えると 安定化効果があり，Fig. 22 に示すように粒子径が小さく なるにつれて不安定になることが示された ${ }^{76)}$ 。

\section{$5 \cdot 4$ ポリマーの効果}

ポリマーは, 従来の安定剤が効果を示さない場合や, 特別な泡用途での応用に有効である。親水性ポリマーの 泡安定化剂として, 寒天, アルギン酸ナトリウム, PVA などが知られている。ポリマーは泡膜表面もしくはバル ク粘度を上げることで, 泡膜弾性の増加, 排液速度の低 下を示し, 泡膜を安定化させる。Goddardらは, SDS に対するカチオン化セルロース（Polymer JR）の効果 を報告している ${ }^{77)}$ 。表面粘度の増加によって泡沫の安定 性が増すことを示した。Laiらは, 洗浄剂の泡安定化剂

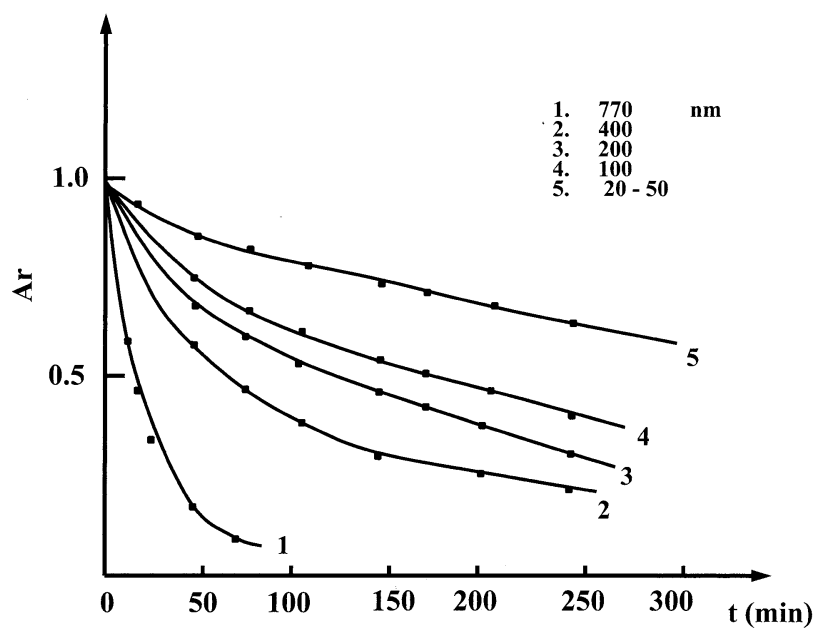

Fig. $22 \mathrm{SDS}$ の泡沫の安定性におよほす疎水化 $\mathrm{SiO}_{2}$ の粒子 径の影響
としてヒドロキシグアーガム誘導体を提唱し，US パテ ントを取得している ${ }^{78)}$ 。水溶性のセルロースセル誘導体 に，メチルセルロースやヒドロキシプロピルセルロース がある。これらポリマーの溶液を加熱すると，ゲル相を 呈しこの状態で泡膜を安定にするが，ゲル化温度はポリ マー量に依存し, 濃度の増加とともにゲル化温度は低下 する。これらポリマーの疎水化は，ポリマーの表面吸着 性を高め，泡膜の安定化は表面吸着層による機械的安定 性の向上によるものである。

バイオポリマーの効果として，食品分野でよく使われ ている一般的なものは，タンパク質，リン脂質および夕 ンパク質の複合体である。基本的なバイオポリマーの効 果は Poole の総説に詳しいが79), タンパク質による気液 界面の安定化は，凝集した吸着状態となるため，膜が粘 弾性を持つためと説明されている ${ }^{80)}$ 。

\section{$5 \cdot 5$ 液晶の効果}

1972 年に Friberg らが初めて液晶による泡膜の安定化 効果を報告 ${ }^{81)}$ して以来，多くの報告が行われてきた ${ }^{82)}$ 。 親油性界面活性剂と炭化水素が作る等方性溶液相に，水 を添加してできる液晶相との境界に出現する 2 相共存領 域で安定な泡膜が形成される。この応用例としてシェー ビングクリームがあり，安定化機構としては，液晶形成 による排液の遅延，および気液界面への液晶吸着による 表面粘度の増加が提唱されている。また, Petrovらは, 非イオン界面活性剤の液晶形成による泡膜の安定化を示 した ${ }^{83)}$ 。

\section{6 おわりに}

界面活性剂の液体膜は，希薄系においては液体の粘性 が低いことから，表面力がその安定性に大きく寄与す る。そのため, 液膜厚みにより表面粘弾性や分離圧など 安定性に大きく寄与する主因子が変化してくる。しかし ながら, 濃厚系や高分子物質により安定化した液膜は, そのほとんどがバルク液体の粘弾性の大きさに支配され ることとなる。すなわち，液体の粘性が増すことによ り，それを変形させるには表面力だけではあまりに非力 であることを物語っている。応力とひずみが対をなす弾 性力と，変形速度の大きさとひずみが対をなす粘性力 が，液膜の安定化を考える主役となる。したがって，本 稿で解説した表面力の考えは, 実用的観点からは限られ た読者の参考となるにすぎないことは否めない。しかし ながら，極めて薄い泡膜や瞬間的な表面張力の低下をと もなう製品群などにおいては，やはり界面活性剤の速や かな吸着にともなう表面力のコントロールが求められ る。泡膜に対する総合的な理解を深めることで, 機能的 に秀でた液体製品が設計できることを確信するとともに 
本説が，産業界の皆様への応用に拉ける基礎知見として も活用いただけることを願ってやまない。

\section{文献}

1）田村隆光，表面, 38, 22 (2000).

2) I.B. Ivanov \& D.S. Dimitov, Thin Liquid Films: Fundamentals and Applications, Marcel Dekker, New York p.379 (1988).

3) A. Sheludko, Adv. Colloid Interface Sci., 1, 391 (1967).

4) A.K. Malhotra \& D.T. Wasan, Chem. Eng. Comn., 55, 95 (1987).

5) R.J. Pugh \& D. Exerowa, Adv. Colloid Interface Sci., 64, 67 (1996).

6) D. Exerowa, T. Kolalov \& K.H.R. Khristov, Colloids Surf., 22, 171 (1987).

7) A.D. Nikolov \& D. T. Wasan, J. Colloid Interface Sci., 133, 1 (1989).

8) E. Manev \& R.J. Pugh, Langmuir, 7, 2253 (1991).

9) V. Bergeron \& C.J. Radke, Langmuir, 8, 3020 (1992).

10) M.N. Jones, K.J. Mysels \& P.C. Scholten, Trans Faraday Soc., 62, 1336 (1966).

11) H.J. Müller \& Th. Rheintänder, Langmuir, 12, 2334 (1996).

12) A. Prins, C. Arcuri \& V.D. Temple, J. Colloid Interface Sci., 24, 84 (1967).

13) T. Yamanaka, Bull. Chem. Soc. Jpn., 43, 633 (1970).

14) K.J. Mysels, J.Phys. Chem., 68, 3441 (1964).

15) J. Umemura \& T. Kawai, Can. J. Chem., 94, 62 (1990).

16) H.N. Stein, Adv. Colloid Interface Sci., 34, 175 (1991).

17) A.K. Malhotra \& D.T. Wasan, Chem. Eng. Comm., 55, 95 (1987).

18) N.C. Mishra, H.-J. Müller, H. Möhwald \& R. Krastev, Colloids Surf. A, 282-283, 92 (2006).

19) T. Tamura \& Y. Kaneko, Surface and Interfacial Tension: Measurement, Theory and Applications (S. Hartland ed.) p. 91, CRC Press, New York (2004).

20) D. Exerowa, T. Kolarov \& KHR. Khristov, Colloids Surf., 22, 171 (1987).

21) C. Stubenrauch \& R. Strey, Langmuir, 20, 5185 (2004).

22) R.-H. Yoon \& L. Wang, Colloids and Interface Science Series, 1, 161 (2007).

23) R.-H. Yoon \& L. Wang, Langmuir, 24, 5194 (2008).

24) L. Wang \& R.-H. Yoon, Minerals Engineering, 19, 539 (2006).

25) L. Wang \& R.-H. Yoon, Colloids Surf. A, 282-283, 84 (2006).

26) L. Wang \& R.-H. Yoon, Colloids Surf. A, 263, 267 (2005).

27) R.-H. Yoon \& B.S. Aksoy, J. Colloid Interface Sci., 211, 1 (1999).

28) L. Wang \& R.-H. Yoon, Langmuir, 20, 11457 (2004).

29) V.S.J. Craig, B.W. Ninham \& R.M. Pashley, J. Phys. Chem., 97, 10192 (1993).

30) A. Vrij \& Th.G. Overbeek, J. Am. Chem. Soc., 90, 3074 (1968).

31) E. Santini, F. Ravera, M. Ferrari, C. Stubenrauch, A. Makievski \& J. Krägel, Colloids Surf. A, 298, 12 (2007).
32) C. Stubenrauch \& R. Miller, J. Phys. Chem. B, 108, 6412 (2004).

33) L. Liggieri, V. Attolini, M. Ferrari \& F. Ravera, J. Colloid Interface Sci., 255, 225 (2002).

34) V.B. Fainerman, J.T. Petkov \& R. Miller, Langmuir, 24, 6447 (2008).

35) D. Beneventi, R.J. Pugh. B. Carré \& A. Gandini, J. Colloid Interface Sci., 268, 221 (2003).

36) K.D. Danov, P.A. Krachevsky \& I.B. Ivanov, Handbook of Detergents, Part A: Properties, Marcel Dekker, New York, p. 303 (1999).

37) I.B. Ivanov \& D.S. Dimitov, Thin Liquid Films: Fundamentals and Applications (I.B. Ivanolv ed..) Marcel Dekker, New York, p. 379 (1988).

38) D. Kashiev \& D. Exerowa, J. Colloid Interface Sci., 77, 501 (1980).

39) D. Exerowa, B. Balinov \& D. Kashiiev, J. Colloid Interface Sci., 94, 45 (1983).

40) D. Exerowa \& D. Kashiev, Contemp. Phys., 27, 429 (1986).

41) T. Kolarov, R. Cohen \& D. Exerowa, Colloids Surf., 42, 49 (1989).

42) H.J. Müller \& Th. Rheinländer, Langmuir, 12, 2334 (1996).

43) C. Stubenrauch, R. Cohen \& D. Exerowa, Langmuir, 23, 1684 (2007).

44) T. Tamura, Y. Kaneko \& M. Ohyama, J. Colloid Interface Sci., 173, 493 (1995).

45) H. Kimizawa \& T. Sasaki, Bull. Chem. Soc. Jpn., 24, 230 (1951).

46) E. Ruckenstein \& A. Shama, J. Colloid Interface Sci., 119, 1 (1987).

47) D.T. Wasan, A.D. Nikolov, L.A. Lobo, K. Koczo \& D.A. Edwards, Progr. Surf. Sci., 39, 119 (1992).

48) D.O. Shah, N. F. Djabbarab \& D. T., Wasan, Colloid Polym.Surf., 256, 1002 (1978).

49) 清宮 禁, 油化学, 42, 719 (1993).

50) T. Tamura, Y. Kaneko \& M. Nikaido, J. Colloid Interface Sci., 190, 61 (1997).

51) T. Tamura, T. Takeuchi \& Y. Kaneko, J. Colloid Interface Sci., 206, 112 (1998).

52) K.-Y. Lai \& N. Dixit, Foams, Marcel Dekker, New York, p. 315, (1996).

53) A.G. Brown, W.C. Thuman \& J.W. McBain, J. Colloid Interface Sci., 8, 491 (1953).

54) G.D. Miles, L. Shedovsky \& J. Ross, J. Phys. Chem., 49, 93 (1945).

55) L. Shedlovsky, J. Ross \& C.W. Jakob, J. Colloid Interface Sci., 4, 25 (1949).

56) M.J. Schick \& F.M. Fowkes, J. Phys. Chem., 61, 1062 (1957).

57) H.C. Kung \& E.D. Goddard, J. Phys. Chem., 68, 3465 (1964).

58) W.M. Sawyer \& F.M. Fowkes, J. Phys. Chem., 68, 3511 (1964).

59) P. Becher \& A.J. Del Vechio, J. Phys. Chem., 62, 159 
(1958).

60) G.D. Miles \& J. Ross, J. Phys. Chem., 48, 280 (1944).

61) J. Krichevsky \& H.L. Sangers, ISI Congr. Mondial Detergence et Prods. Tensioactifs, Paris, 1, 133 (1954).

62) U. S. Patent 2, 169,976 (1939); U. S. Patent 3,001,945 (1951).

63) U. S. Patent 2, 169, 676 (1961).

64) Belgian Patent 603, 337 (1961).

65) T.P. Matson, J.Am. Oil Chem. Soc., 40, 640 (1963).

66) D.G. Kolp, R.G. Laughlin, F. P. Krause \& R.E. Zimmerer, J.Phys. Chem., 67, 51 (1963).

67) M.J. Rosen, D. Friedman \& M. Gross, J. Phys. Chem., 11, 3219 (1964).

68) M. Camp \& K. Durham, J.Phys. Chem., 59, 993 (1955).

69) R.L. Bendure, Tappi, 58, 83 (1975).

70) M. Baviere, B. Bazin \& R. Aude, J. Colloid Interface Sci., 92, 580 (1983).

71) J.M. Peacock \& E. Matijevic, J. Colloid Interface Sci., 77, 548 (1980).
72) R.S. Kumar \& G. Bhat, J. Am. Oil Chem. Soc., 64, 556 (1987).

73) H. Scoff, J. Am. Oil Chem. Soc., 65, 1058 (1988).

74) Z. Hoffman, Physik Chem., 83, 385 (1913).

75) L.D. Skryler, V.V. Sviridev, F.L. Molochnikova \& L.A. Kuzumia, Zh. Prill Khim (Leningrad), 47, 797 (1974).

76) F.Q. Tang, Z. Xiao, J.A. Tang \& L. Jiang, J. Colloid Interface Sci., 131, 498 (1989).

77) E.D. Goddard \& R.B. Hannan, J. Colloid Interface Sci., 55, 73 (1976).

78) U. S. Patent 4, 877, 546 (1989).

79) S. Poole, Int. J. Food Sci. Tech., 24, 121 (1989).

80) A. Vrij, Discuss Faraday Soc., 42, 23 (1966).

81) S. Friberg \& S. I. Ahmed, J. Colloid Interface Sci., 35, 175 (1971).

82) S. Friberg, Advances in Liquid Crystals, Academic Press, p. 149 (1978).

83) A.G. Petrov \& S. Naidenova, J.Dispers. Sci. Technol., 1, 283 (1980). 